\title{
Breast Milk Macronutrients in Relation to Infants' Anthropometric Measures
}

\author{
Enas R. Abdelhamid ${ }^{1}$, Alyaa H. Kamhawy ${ }^{1 *}$, Alshaimaa A. Elkhatib ${ }^{1}$, Amr S. Megawer $^{2}$, Amal I. El Shafie $^{3}$, Yasmin G. El Gendy ${ }^{4}$, \\ Dina E. A. Rabie ${ }^{4}$ \\ ${ }^{1}$ Department of Child Health, Medical Division, National Research Center, Dokki, Giza, Egypt; ${ }^{2}$ Department of Pediatrics, \\ Research Institute of Ophthalmology, Giza, Egypt; ${ }^{3}$ Department of Health Radiation Research, National Center for Radiation \\ Research and Technology, Atomic Energy Authority, Cairo, Egypt; ${ }^{4}$ Department of Pediatrics, Ain Shams University, Cairo, \\ Egypt
}

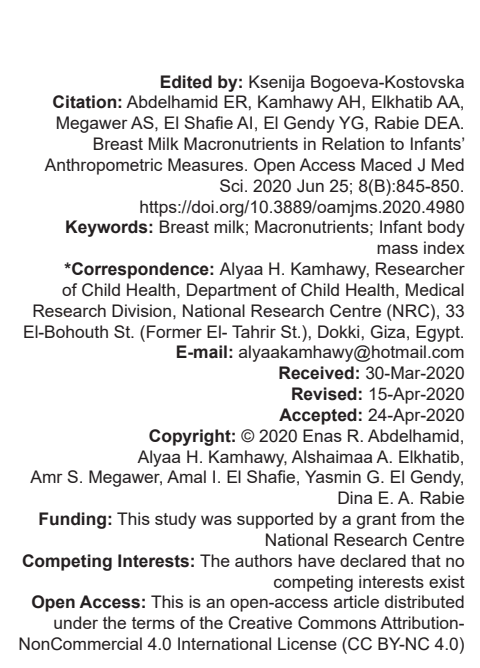

Introduction

Breast milk (BM) is a rich complex nutrition source and is key to a baby's health, growth, and development [1].

Advantages of breastfeeding on the health and the infant wellbeing are well known, including prohibition of infections, optimal neurodevelopment, and may restrict the occurrence of allergy, diabetes, and obesity later in life [2], [3].

BM contains the main essential macro and micronutrients a human infant needs for early in life, the principal components of human milk (HM) are carbohydrates, proteins, lipids, vitamins, minerals, and other trace elements [4].

Carbohydrates are mostly lactose; several lactose-based oligosaccharides have been also known but as minor components. Fat portions have specific triglycerides of oleic and palmitic acid, also lipids with trans bonds. The lipids have conjugated linoleic acid and vaccenic acid, which represent for up to $6 \%$ of the fat in $\mathrm{HM}$ [5]. Lipids in HM supply the infant with essential vitamins and energy, bioactive components, and polyunsaturated fatty acids. Recent studies showed that breastfeeding providing arachidonic acid and docosahexaenoic acid which improve cognitive development and reduce asthma risk at school-age children [6].

The principal proteins are $\lg \mathrm{A}$, lysozyme, alpha-lactalbumin, and lactoferrin (apo-lactoferrin) [7].

The World Health Organization encourages and maintains breastfeeding by theiractive recommendations that all infants must be exclusively breastfed for the first 6 months of life and that breastfeeding should be continued with the proper complementary foods for 2 years and beyond postpartum [8].

Nutritional components of HM derive from three sources: Some originate from the diet, some are created 
from maternal stores, and some of the nutrients of milk originate by the synthesis in the lactocyte. Overall, the nutritional quality of $\mathrm{HM}$ is highly preserved, but care to the maternal diet is of great importance for the fatty acid composition and some vitamins of HM [9].

HM composition changes greatly between mothers and even within a single milk expression. This large variation in milk composition is supposed to be an adaptation to the infants' change in demands [10]. Moreover, it is influenced by numerous maternal, genetic, and environmental factors [4].

The colostrum and transitional milk in the early days of initiation of lactation vary greatly and are different in many ways from mature milk. Mature milk stays quite the same in composition with minor changes throughout the duration of lactation. The nutritional value is also different between preterm and term HM [11].

Breastfed infants increase largely in length, weight, and body mass index (BMI) during the first 2-3 months of newborn life and then reach a slower rate of growth over the next 12 months. They also have a larger fat accumulation in early infancy. Recent studies have found strong relations between BM composition (protein, total fat, adiponectin, leptin, HM oligosaccharides, and insulin) and velocity of infant growth. More studies, including studies of maternal factors affecting BM composition, are in need for more understanding how breastfeeding affects the present and final rate of growth and thereby short- and longterm health [12]

\section{Subjects and Methods}

\section{Study design and target population}

One hundred exclusively breastfeeding lactating women were recruited from September 2019 to December 2019 from outpatient clinic El Demerdash Hospital Ain Shams University. Written informed consent was taken in advance from the mother of each infant. The study had the ethical approval of the medical research committee at the National Research Center, having number 201007.

\section{Infant anthropometric measurements}

Infants were measured by a trained pediatric nurse, with weight and length. Weight was taken to the nearest $1 \mathrm{~g}$ using a Seca 757 electronic baby scale (Seca, Birmingham, UK). Supine length was calculated to the nearest $0.1 \mathrm{~cm}$ using a Seca 416 Infantometer (Seca, Birmingham, UK). BMI was then calculated (Tables 1 and 2) [13].

\section{Maternal data recording}

Age of mothers, parity, and nutritional habits was recorded. Detailed dietetic history about food patterns, food intake, and regularity of meals was obtained.

\section{Milk collection and analysis}

Women shared in the study donated their Hind BM samples through expression using Medela Symphony electric pump [14]. Milk samples were analyzed in the laboratory of the Dairy Sciences Department, Food Industry and Nutrition Research Division, National Research Center.

\section{Total fat determination}

Fat percentage was detected according to British Standard Institution by Gerber method [15] by placing 10 $\mathrm{ml} \mathrm{H}_{2} \mathrm{SO}_{4}$ first into butyrometer then introduce of 10.75 $\mathrm{ml}$ of milk slowly, so the milk and $\mathrm{H}_{2} \mathrm{SO}_{4}$ do not mix with each other. Finally we add $1 \mathrm{ml}$ of Amyl alcohol. The three contents added vigorously then centrifuge for about $5 \mathrm{~min}$, butyrometer then put in hot water bath for another $5 \mathrm{~min}$, finally fat concentration was detected and measured [16].

Total protein determination: Protein concentration was assessed using the semi-micro Kjeldahl distillation method, according to Ling [17]. $5 \mathrm{gm}$ of milk was put in into $100 \mathrm{ml}$ flask. Then, it diluted to the mark with water, mix, and pipet $20 \mathrm{ml}$ into a 300-ml Kjeldahl digestion flask. After adding of catalytic factors, sodium sulfate and nitrogen-free sulfuric acid were then added.

$\mathrm{NaOH}$ solution and distilled water were added, then the sample steam-distilled for approximately 10 min, adding of methyl red-methylene blue and a weak acid like a boric acid solution to receive ammonia [18].

Lactose determination: Lactose content was measured calorimetrically, according to Barnett and Abd El-Tawab [19]. As lactose is a disaccharide sugar which splits into glucose and galactose in the presence of lactase enzyme. Glucose reacts with a phenolic compound such as phenol-sulfuric acid through an enzymatic reaction, forming a pink colored complex. The resultant compound absorbance was read at 505 $\mathrm{nm}$, of note that the color becomes darker as the lactose concentration increase.

Table 1: Descriptive data of the studied infants and mothers

\begin{tabular}{lll}
\hline Variable & Range & Mean \pm SD \\
\hline Infant age (by month) & $6-14$ & $9.40 \pm 3.21$ \\
Gest. age (by week) & $36-42$ & $38.11 \pm 1.21$ \\
Wt. (by kg) & $6.5-11.5$ & $9.15 \pm 1.26$ \\
Length (by cm) & $64-78$ & $69.45 \pm 4.39$ \\
Infants BMl & $15.8-18.1$ & $16.70 \pm 1.20$ \\
Maternal age (by year) & $24-30$ & $27.46 \pm 2.35$ \\
\hline SD: Standard deviation, BMl: Body mass index. & &
\end{tabular}

Samples of milk were examined for total solids, true protein, fat, and lactose according to A.O.A.C. procedures. The ash content of milk was analyzed after a milk sample is heated in a muffle furnace at $550{ }^{\circ} \mathrm{C}$ for $8 \mathrm{~h}$ [20]. 
Table 2: Food pattern and regularity of meals of the studied mothers

\begin{tabular}{lll}
\hline Items & $\mathrm{n}$ & $\%$ \\
\hline Breakfast regularly & 43 & 73.0 \\
Protein in breakfast regularly & 55 & 55.0 \\
Lunch regularly & 92 & 92.0 \\
Protein in lunch regularly & 78 & 78.0 \\
CHO in lunch regularly & 86 & 86.0 \\
Dinner regularly & 64 & 64.0 \\
\hline
\end{tabular}

\section{Statistical analysis}

Analysis was performed using SPSS version 23.0 (SSPS Inc., Pennsylvania, USA). Mean \pm SD and percent were used for parameters' distribution calculations. Correlation was done using Person's correlation (Table 3).

Table 3: Macronutrients in breast milk of the studied maternal sample

\begin{tabular}{ll}
\hline Items & $\mathbf{n = 1 0 0}$ \\
\hline FAT $(\mathrm{g} / 100 \mathrm{~g}$ milk) & \\
Mean \pm SD & $4.58 \pm 0.94$ \\
Range & $3-7.75$ \\
Protein (g/100 g milk) & $1.06 \pm 0.28$ \\
Mean \pm SD & $0.5-1.8$ \\
Range & $6.52 \pm 0.97$ \\
Lactose $(\mathrm{g} / 100 \mathrm{~g}$ milk) & $4.7-9.4$ \\
$\quad$ Mean \pm SD & \\
Range &
\end{tabular}

\section{Results}

Negative significant correlation was detected between $\mathrm{BM}$ fat and infants $\mathrm{BMI}$; furthermore, negative correlation was detected between breast milk fat and gestational age as shown in Figure 1.

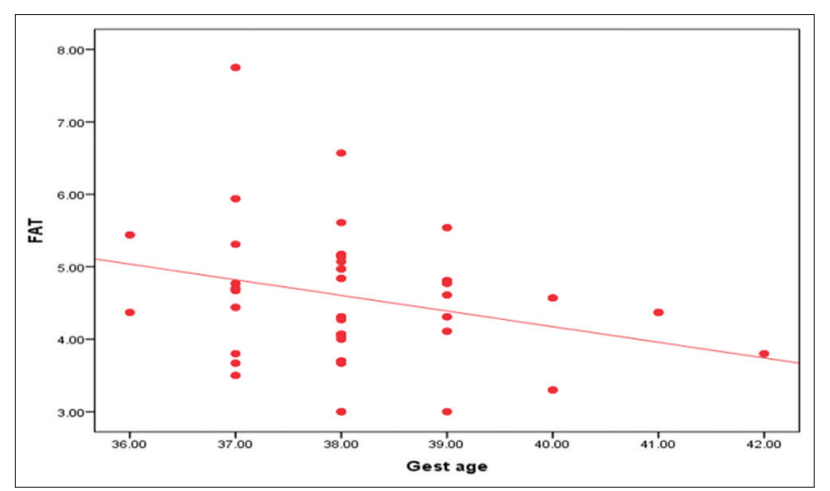

Figure 1: Relationship between breast milk fat and gestational age $(r=-0.238)$

While, a significant positive correlation was found between BM protein and infants' age. Furthermore, a highly positive significant correlation was found between BM lactose and infants' age (Table 4).

Table 4: Relationship between breast milk macronutrients and different variables in the studied infants

\begin{tabular}{|c|c|c|c|c|c|c|}
\hline \multirow[t]{2}{*}{ Variable } & \multicolumn{2}{|c|}{ Breast milk fat } & \multicolumn{2}{|c|}{ Breast milk protein } & \multicolumn{2}{|c|}{ Breast milk lactose } \\
\hline & $r$ & $p$ & $r$ & $\mathrm{p}$ & $\mathrm{r}$ & $p$ \\
\hline Infant BMI & $-0.210^{*}$ & 0.036 & 0.048 & 0.636 & 0.040 & 0.692 \\
\hline Infant age (by month) & 0.087 & 0.390 & $0.235^{*}$ & 0.019 & $0.273^{\star *}$ & 0.006 \\
\hline Infant wt. (by kg) & -0.135 & 0.182 & 0.112 & 0.266 & 0.030 & 0.767 \\
\hline Infant length (by cm) & -0.008 & 0.936 & 0.099 & 0.327 & 0.001 & 0.991 \\
\hline Gest. age (by week) & $-0.238^{*}$ & 0.017 & 0.121 & 0.230 & -0.109 & 0.279 \\
\hline
\end{tabular}

A significant negative correlation was detected between breast milk fat and maternal age. Furthermore, a significant negative correlation was detected between breast milk protein and parity (Table 5).

Table 5: Relationship between breast milk macronutrients and different studied maternal variables

\begin{tabular}{|c|c|c|c|c|c|c|}
\hline \multirow[t]{2}{*}{ Items } & \multicolumn{2}{|c|}{ Breast milk fat } & \multicolumn{2}{|c|}{ Breast milk protein } & \multicolumn{2}{|c|}{ Breast milk lactose } \\
\hline & $r$ & $p$ & $R$ & $\mathrm{p}$ & $r$ & $p$ \\
\hline \multicolumn{7}{|l|}{ Maternal variables } \\
\hline Maternal age (by year) & $-0.237^{*}$ & 0.017 & 0.134 & 0.185 & 0.040 & 0.692 \\
\hline Parity & 0.020 & 0.846 & $-0.232^{*}$ & 0.020 & -0.120 & 0.234 \\
\hline Mother wt. (by kg.) & 0.032 & 0.752 & -0.042 & 0.677 & 0.165 & 0.101 \\
\hline Mother height (by $\mathrm{cm}$.) & $0.229^{*}$ & 0.022 & 0.160 & 0.112 & $0.270^{\star *}$ & 0.007 \\
\hline Mother BMI & -0.105 & 0.299 & -0.118 & 0.240 & 0.048 & 0.638 \\
\hline
\end{tabular}

Mean protein concentration in a group of mothers who got protein in lunch was higher than the other group who did not; the difference between both groups was highly significant (Table 6).

Table 6: Breast milk protein content in relation to infant gender and maternal food patterns

\begin{tabular}{llll}
\hline Variable & Protein Mean \pm SD & Test value & -value \\
\hline Infant gender & & & \\
$\quad$ Male & $1.09 \pm 0.25$ & 1.604 & 0.112 \\
$\quad$ Female & $0.99 \pm 0.33$ & & \\
Breakfast & $1.28 \pm 0.28$ & 5.430 & 0.000 \\
$\quad$ No & $0.97 \pm 0.24$ & & \\
$\quad$ Yes & $1.15 \pm 0.30$ & 3.027 & 0.003 \\
Protein in breakfast & $0.98 \pm 0.24$ & & \\
$\quad$ No & & & \\
$\quad$ Yes & $0.91 \pm 0.26$ & -1.511 & \\
Lunch & $1.07 \pm 0.28$ & & \\
$\quad$ No & & & \\
Yes & $0.92 \pm 0.24$ & -2.676 & \\
Protein in lunch & $1.09 \pm 0.28$ & & \\
$\quad$ No & $1.04 \pm 0.28$ & -0.289 & \\
$\quad$ Yes & $1.06 \pm 0.28$ & & \\
CHO in lunch & & & \\
$\quad$ No & $1.12 \pm 0.25$ & & \\
$\quad$ Yes & $1.02 \pm 0.29$ & & \\
Dinner & No & &
\end{tabular}

\section{Discussion}

Many studies have investigated how the composition of $\mathrm{HM}$ is in strong relation to infant growth. Recent observational researches have shown that BM concentrations of carbohydrate, fat, and protein are likely to have a strong influence on infant growth and body composition [21], [22].

The composition of $\mathrm{HM}$ is dynamic and complex, and many valuable considerations are important when discussing the strong association between infant growth and HM composition [9].

Studies showed that the amino acid composition of HM has an impact on growth, not only its concentration. Moreover, free amino acid concentration have an appetite regulating effect [23].

Many studies found that a higher intake of $\mathrm{HM}$ lactose can encourage the storage of glycogen and fat, and so promote growth [21].

It was suggested that fat percentage in $\mathrm{HM}$ may slow growth velocity, as it was associated with lower infancy weight and adiposity [23] 
Analysis of the composition of mother's milk allows one to assess its nutritional value [14]. BM includes complex carbohydrates, proteins, lipids, and other biologically active components. The composition varies largely over a single feed as well as over the whole duration of lactation [24].

BM volume and composition are influenced by many factors such as delivery time, lactation stage [25], and prematurity which is shown to play a role also [26], recent studies reported that composition of BM could be tailored by each mother to meet the requirements of her infant [27].

Duration of breastfeeding is associated with reduced risk of developing obesity later in life [2], [28]. These observations suggest a dose-dependent effect of breastfeeding on the development of infant body composition, but the mechanisms of this effect are not fully understood [29], [30].

Our data revealed that fat content in BM was negatively correlated with infants' BMI, which fit that reported by Prentice et al. [23]. This could be explained by that low BM fat concentration makes the infant feel less satisfied and in need for increasing volumes of milk, hence more weight gain.

This work results showed that BM fat content was negatively correlated with gestational age, this was in concordance with a study of Fouad et al. [31]. Current results suggested that with a decrease in gestational age, the BM volume also decreases; consequently, the concentration of some nutrients such as fat appears to increase.

A negative correlation between BM fat content and maternal age was detected in the current study, which coincides with that of Fouad et al. [31]. The results of our study could be explained by exhaustion or depletion of body stores with a decrease of the amount of functional tissue in the breasts with the progression of age (disuse atrophy). In the contrary, studies of Heffner et al. [32] and of Lubetzky et al. [33] revealed that fat content did not affect by mothers' ages.

Current results documented a positive correlation between BM protein content and infant age, this finding could be explained by the adaptation of milk composition to the increased energy demand of the intensively growing child. Likewise, the study of Czosnykowska-Lukacka et al. [14] documented that the protein content of BM increased significantly with the duration of lactation. In the contrary, the study of Hascoët et al. [34] came with different results, as it reported that BM protein concentrations were negatively correlated with the duration of lactation from birth onwards.

This work showed a negative significant correlation between protein content of BM and parity, which is consistent with the publication of Bachour et al. [35], who showed that proteins decrease with increasing parity.
Suggested explanation is that the body reserve of proteins depletes with every successive pregnancy.

$78 \%$ of our sample were taking protein on daily basis in their lunch meal, our results showed that this group had higher level of breast milk protein.

The current finding could be explained by direct transfer of maternal dietary proteins from plasma to BM which adds to the protein synthesized in the mammary secretory cell. In contrary to studies of Bauer and Gerss [36], and Aumeistere et al. [37], both revealed that concentration of $\mathrm{HM}$ protein is not affected by maternal diet.

A positive correlation between BM lactose content and infant age was detected in this study, the same as that of Hascoët et al. [34]. This could be explained by increasing milk volume with the age of the infant as a compensatory mechanism for increasing demand; this, in turn, is associated with an increase in lactose concentration.

BMcarbohydratecontent(lactose)was positively correlated with protein and fat content in our samples'BM. It fit the same reported by Hascoët et al. [34]. However, in contrary to Czosnykowska-Lukacka et al. [14], whose study showed a negative correlation between the main three macronutrients.

Our study reported no difference in BM composition in relation to infant's sex; likewise, van de Heijning et al. [38].

To the best of our knowledge, this is a point of conflict between many studies, the study of Hahn et al. [39] reported that BM was higher in energy for female infants in Korean and Kenyan mothers. In the contrary, the study of Powe et al. [40] found that mothers of male infants produced milk that had $25 \%$ greater energy content than mothers of female infants.

\section{Conclusion}

Current study confirms that breast milk macronutrients composition has a wide variability, this variability is associated with each macronutrient respectively. To improve breast milk composition one could aim for improving the nutritional balance in lactating women, especially for protein intake. More well-designed longitudinal studies about factors that influence human milk compositions are warranted.

\section{Acknowledgment}

We would like to thank the National Research Centre (in-house office for research projects) for the 
research grants supported this work. Furthermore, we would like to thank Associate Professor H. H. Azzaz at Dairy Sciences Department, Food Industry and Nutrition Research Division, National Research Center for his help and assistance.

\section{References}

1. Butts CA, Hedderley DI, Herath TD, Paturi G, Glyn-Jones S, Wiens $F$, et al. Human milk composition and dietary intakes of breastfeeding women of different ethnicity from the ManawatuWanganui region of New Zealand. Nutrients 2018;10(9):1231. https://doi.org/10.3390/nu10091231

PMid:30181524

2. Victora CG, Bahl R, Barros AJ, França GV, Horton S, Krasevec J, et al. Breastfeeding in the $21^{\text {st }}$ century: Epidemiology, mechanisms, and lifelong effect. Lancet 2016;387(10017):47590. https://doi.org/10.1016/s0140-6736(15)01024-7 PMid:26869575

3. Manti S, Lougaris V, Cuppari C, Tardino L, Dipasquale V, Arrigo $\mathrm{T}$, et al. Breastfeeding and IL-10 levels in children affected by cow's milk protein allergy: A restrospective study. Immunobiology 2017;222(2):358-62. https://doi.org/10.1016/j. imbio.2016.09.003

PMid:27622938

4. Stam J, Sauer PJ, Boehm G. Can we define an infant's need from the composition of human milk? Am J Clin Nutr 2013;98(2):5218. https://doi.org/10.3945/ajcn.112.044370

\section{PMid:23842459}

5. Friesen R, Innis SM. Trans fatty acids in human milk in Canada declined with the introduction of Trans fat food labeling. J Nutr 2006;136(10):2558-61. https://doi.org/10.1093/jn/136.10.2558

6. Koletzko B. Human milk lipids. Ann Nutr Metab 2016;69(2):28-40. PMid:28103608

7. Demmelmair H, Prell C, Timby N, Lonnerdal B. Benefits of lactoferrin, osteopontin and milk fat globule membranes for infants. Nutrients 2017;9(8):817. https://doi.org/10.3390/ nu9080817

PMID: 28788066

8. World Health Organization. World Health Organization 10 Facts on Breastfeeding February 2018. Geneva: World Health Organization; 2018.

9. Ballard O, Morrow AL. Human milk composition: Nutrients and bioactive factor. Pediatr Clin North Am 2013;60(1):49-74. PMid:23178060

10. Sauer CW, Boutin MA, Kim JH. Wide variability in caloric density of expressed human milk can lead to major underestimation or overestimation of nutrient content. J Hum Lact 2017;33(2):341 50. https://doi.org/10.1177/0890334416672200 PMid:28418793

11. Gidrewicz DA, Fenton TR. Asystematic review and meta-analysis of the nutrient content of preterm and term breast milk. BMC Pediatr 2014;14:216. https://doi.org/10.1186/1471-2431-14-216 PMid:25174435

12. Lind MV, Larnkjær A, Mølgaard C, Michaelsen KF. Breastfeeding, breast milk composition, and growth outcomes. Nestle Nutr Inst Workshop Ser 2018;89:63-77. https://doi. org/10.1159/000486493

13. Medhat H. Shehata1, Hamed A. Elkayat, Adel N. Hanna, Zakaria A. El-Khiyat, Iman H. Kamel, and Alyaa H Kamhawy.
Study of retinol and the retinol binding protein 4 in cases of overweight and obese adolescents. Res J Pharm Biol Chem Sci 2016;7(6):1165-75

14. Czosnykowska-Lukacka M, Krolak-Olejnik B, OrczykPawitowicz M. Breast milk macronutrient components in prolonged lactation. Nutrients 2018;10(12):1893. https://doi. org/10.3390/nu10121893 PMid:30513944

15. British Standard Institution. Gerber Method for the Determination of Fat in Milk and Milk Products. British Standard Institution; 1951. p. 696.

16. Boci I, Bardhi G, Cakraj R. Total solids and fat determination in milk: Interlaboratory testing. Albanian J Agric Sci 2013;12(1):1-5.

17. Ling ER. Text Book of Dairy Chemistry. London: Chapman and Hall; 1963. p. 559.

18. Michałowski T, Asuero AG, Wybraniec $\mathrm{S}$. The titration in the kjeldahl method of nitrogen determination: Base or acid as titrant? J Chem Educ 2013;90(2):191-7. https://doi.org/10.1021/ ed200863p

19. Barnett AJ, Abd El-Tawab G. Determination of lactose in milk and cheese. J Sci Food Agric 1957;8:437.

20. AOAC. Official Methods of Analysis of AOAC International. Agricultural, Chemicals, Contaminants, Drugs. Vol. 16. Washington, DC, USA: AOAC; 1995.

21. Eriksen KG, Chritensen SH, Lind MV, Michaelsen KF. Human milk composition and infant growth. Curr Opin Clin Nutr Metab Care 2018;21(3):200-6. PMid:29461264

22. El Ashmawy EA, El Wakeel MA, El Ghoroury EA. Types of feeding in infancy: Further observation of intestinal blood loss and iron deficiency anaemia. J Appl Sci Res 2012;8(3):1460-5.

23. Prentice $P$, Ong KK, Schoemaker MH, Van Tol EA, Vervoort J, Hughes IA, et al. Breast milk nutrient content and infancy growth. Acta Pædiatr 2016;105(6):641-7. https://doi.org/10.1111/ apa.13362

PMid:26865238

24. Andreas NJ, Kampmann B, Le-Doare KM. Human breast milk: A review on its composition and bioactivity. Early Hum Dev 2015;91(11):629-35. https://doi.org/10.1016/j. earlhumdev.2015.08.013 PMid:26375355

25. Gomez-Gallego C, Garcia-Mantrana I, Salminen S, Collado MC. The human milk microbiome and factors influencing its composition and activity. Semin Fetal Neonatal Med 2016;21(6):400-5. https://doi.org/10.1016/j.siny.2016.05.003 PMid:27286644

26. Hahn WH, Song JH, Song S, Kang N. Do gender and birth height of infant affect calorie of human milk? An association study between human milk macronutrient and various birth factors. J Matern Fetal Neonatal Med 2017;30:1608-12. https:// doi.org/10.1080/14767058.2016.1219989 PMid:27482600

27. Castellote C, Casillas R, Ramirez-Santana C, Pérez-Cano FJ Castell M, Moretones MG, et al. Premature delivery influences the immunological composition of colostrum and transitional and mature human milk. J Nutr 2011;141:1181-7. https://doi. org/10.3945/jn.110.133652

PMid:21508211

28. El Wakeel MA, El-Kassas GM, Kamhawy AH, Galal EM, Nassar MS, Hammad EM, et al. Serum apelin and obesity-related complications in Egyptian children. Open Access Maced J Med Sci 2018;6(8):1354-8. https://doi.org/10.3889/oamjms.2018.312 PMid:30159056

29. Gridneva Z, Rea A, Tie WJ, Lai CT, Kugananthan S, Ward LC, et al. Carbohydrates in human milk and body composition of 
term infants during the first 12 months of lactation. Nurtients 2019;11(7):1472. https://doi.org/10.3390/nu11071472

PMid:31261649

30. El Wakeel MA, El-Kassas GM, Hashem SA, Abouelnaga MW, Elzaree FA, Hassan M, et al. Potential role of oxidative stress in childhood obesity and its relation to inflammation. Biosci Res 2018;15(4):3791-9.

31. Fouad G, Korraa A, Zaglol G, Zaher M, Sadek R. The effect of different techniques of breast milk expression in its fat content in mothers of preterm infants. Med J Cairo Univ 2014;82(1):893-9.

32. Heffner LH, Hausman KM, Mandel DO, Domani KA, Mimouni FB. Advanced maternal age how old is too old? N Engl J Med 2004;351:1927-9. https://doi.org/10.1056/nejmp048087 PMid:15525717

33. Lubetzky R, Sever O, Mimouni FB, Mande D. Human milk macronutrients content: Effect of advanced maternal age. Breastfeed Med 2015;10(9):433-6. https://doi.org/10.1089/ bfm.2015.0072

PMid:26171573

34. Hascoët JM, Chauvin M, Pierret C, Skewers S, Van Egroo L, Rougé $\mathrm{C}$, et al. Impact of maternal nutrition and perinatal factors on breast milk composition after premature delivery. Nutrients 2019;11:366. https://doi.org/10.3390/nu11020366 PMid:30744155

35. Bachour P, Yafawi R, Jaber F, Choueiri E, Abdel-RazzakZ. Effects of smoking, mother's age, body mass index and parity number on lipid, protein and secretory Immunoglobulin A concentrations of human milk. Breastfeeding Med 2012;7(3):179-88. https://doi. org $/ 10.1089 / \mathrm{bfm} .2011 .0038$

\section{PMid:22166069}

36. Bauer J, Gerss J. Longitudinal analysis of macronutrients and minerals in human milk produced by mothers of preterm infants. Clin Nutr 2011;30(2):215-20. https://doi.org/10.1016/j.clnu.2010.08.003 PMid:20801561

37. Aumeistere L, Ciprovica I, Zavadska D, Andersons J, Volkovs V, Celmalniece K. Impact of maternal diet on human milk composition among lactating women in Latvia. Medicina 2019;55(5):173. https://doi.org/10.3390/medicina55050173 PMid:31137596

38. Van de Heijning BJ, Stahl B, Schaart MW, Van der Beek EM, Rings $\mathrm{EH}$, Mearin ML. Fatty acid and amino acid content and composition of human milk in the course of lactation. Adv Pediatr Res 2017;4:16. https://doi.org/10.12715/ apr.2017.4.16

39. Hahn WH, Jeong T, Park S, Song S, Kang NM. Content fat and calorie of human milk is affected by interactions between maternal age and body mass index. J Matern Fetal Neonatal Med 2018;31(10):1385-8. https://doi.org/10.1080/14767058.20 17.1315660

PMid:28523959

40. Powe CE, Knott CD, Conklin-Brittain N. Infant sex predicts breast milk energy content. Am J Hum Biol 2010;22(1):50-4 https://doi.org/10.1002/ajhb.20941

PMid:19533619 